\title{
DEVELOPMENTS WITHIN SOCIAL PEDAGOGY IN AUSTRIA: PERSPECTIVES FOR WORK WITH CHILDREN AND YOUNG PEOPLE
}

\section{Stephan Sting}

\begin{abstract}
This article traces the history of social pedagogy in Austria, which shows some differences from the German history of social pedagogy. In the 1920s and the first half of the 1930s, the development of social pedagogy led to interesting approaches in the field of children's residential care. During the National Socialist era, the emergence of social pedagogy was cut short. After the end of the Second World War, social pedagogy developed step by step into its currently established form, without ever reviving the thinking of the 1920s and 1930s. Nevertheless, I would like to show how the basic concepts of that period offer some inspiration for work with children and young people today. Based on a single case example, I propose a specific approach to social pedagogy, one that seeks to enable educational processes by reflecting and using the opportunities offered by social environments conducive to education. This focuses less on working with and upon the child, and more on changing the relation between child and environment, the "child/ environment nexus".
\end{abstract}

Keywords: child and youth care, child/environment nexus, self-education, history of social pedagogy

Stephan Sting $\mathrm{PhD}$ is a professor of social pedagogy at the Alps-Adriatic University of Klagenfurt, Universitaetsstrasse 65-67, A-9020 Klagenfurt, Austria. Email: Stephan.Sting@aau.at 
In Austria, the development of social pedagogy is closely linked to the history of youth welfare work. From the beginning of the 20th century, care for young people in need of particular support or growing up outside conventional families has been seen in Austria as a pedagogical task that is connected to reflection on social circumstances and that includes the shaping of the social conditions in which people grow up (Scheipl, 2003; Sting, 2015). I would like to show that a specific historical Austrian approach to social pedagogy might offer some interesting inspiration for modern developments in the field of family support.

The attempt to describe specific developments in social pedagogy in Austria first comes up against the question of what Sozialpädagogik (social pedagogy) actually means in the setting of the social and pedagogical occupations. The answer is complicated by several factors. First, in contrast with Germany, scholars in Austria have not systematically developed any theories on social pedagogy. Though there is widespread everyday understanding of social pedagogy, its precise meaning has not been elucidated in the Austrian context. While there are legal regulations for certain social occupations, to date the term Sozialpädagoge [social pedagogue] has not become established as a fixed occupational description. The issue is that social pedagogue is a "term in general use" that cannot be given special protection (Hofmann, 2003, p. 488). Social pedagogy is thus more a pedagogical field than an unambiguous professional category.

Second, there is a tendency in Austria to establish very specific training courses in social pedagogy that have different levels of qualification based on a variety of practical requirements. Some are found only within a certain region. There are, for example, specific training courses for family assistants, childminders, foster parents, those working with out-of-school youth, and those working in the field of leisure activities. A large number of social pedagogical training courses have sprung up, but few general, uniform concepts have been accepted, making it hard to compare the different lines of work or to develop a satisfactory overview (see Scheipl \& Heimgartner, 2004, p. 132).

Third, the theoretical discourses are closely interlinked with the general German-language discussion. In this discussion German approaches and perspectives are dominating and Austrian contributions cannot readily be identified as such. This situation leads to terms and theories being imported that hide any specifically Austrian developments (see Winkler, 2010, pp. 45-46; Scheipl, 2011, pp. 1342-1343).

The development of Austrian social pedagogy led to some interesting approaches in children's residential care in the 1920s and the first half of the 1930s. During the National Socialist era, the development of social pedagogy was cut short. After the end of the Second World War, social pedagogy was taken up again, and evolved step by step into its currently established form, without ever reviving the thinking of the 1920s and 1930s. In what follows I show how the concepts current during that period might inspire work with young people today. Based on the case example of a 24-year-old woman, called "Chantal" in this paper, I propose a specific approach to social pedagogy as a means of reflecting upon educational processes, and enabling them to take 
International Journal of Child, Youth and Family Studies (2018) 9(1): 108-120

place by making use of the opportunities offered by social environments conducive to education. The focus is less on working with and on the child, and more on changing the relation between child and environment, the "child/environment nexus".

\section{Development of Social Pedagogy in the Context of the Discussion on "Wayward Youth"}

In Austria, the history of social pedagogy is closely linked to the emergence of state child and youth care. In Germany, the social pedagogical career profile of the ErzieherIn [educator] covers work in kindergartens (kindergarten teacher) as well as other child and youth care work (child and youth care worker). In Austria, meanwhile, Kindergartenpädagogik [early child care education] has followed its own course of professionalisation, starting in 1872 with specialist courses for kindergarten workers at state colleges of education, leading to separate courses at educational institutions for kindergarten workers (Scheipl \& Heimgartner, 2004, p. 128). Until today, the pedagogical career profile of Austrian kindergarten workers is therefore unlike that of an Austrian teacher, and has few overlaps with other social pedagogical careers or fields of work.

The genesis of professionalisation among social pedagogues is marked by two conferences on child protection, one in Vienna in 1907 and the other in Salzburg in 1913. According to Baernreither (1907), the background to the conferences, and thus the origin of social pedagogical thinking in Austria, was a public impression that "youth waywardness" was on the increase (pp. $\mathrm{v}$-vi). To gain an overview of the situation, reports were compiled by the different regions of the Habsburg Empire. The roots of waywardness were seen as being in the "general social conditions", the main issue being economic problems that made it impossible to maintain the "moral unity of the family" or to raise children effectively. Other issues included poor parenting, and genetic factors directly affecting the children and young people themselves (Baernreither, 1907, p. 3 et seq.).

To solve these problems, bringing up the next generation was declared a task for society as a whole, one that required a systematic state policy on child-raising. Plans were made to establish a comprehensive welfare system concentrating on three fields: child protection (mainly dealing with regulations for foster children and foster parents), correctional education (dealing with residential care), and juvenile criminal law, where the aim was to reinforce the perspective of education when responding to youth delinquency rather than that of punishment (Baernreither, 1907, pp. 19-20). Accordingly, the emergence of social pedagogy is linked to the establishment of a state policy on child-raising that sees the problems of children and young people as childraising problems resulting from social problems and unfavourable living circumstances.

After the end of the First World War, these initial social pedagogical ideas were taken up and developed, especially in Vienna. The theory behind social pedagogical questions was studied especially intensively in the context of the psychoanalytic movement. Siegfried Bernfeld and August Aichhorn, who worked on a theory of waywardness and endeavoured to reform children's residential care in the 1920 s, were key figures. 
Bernfeld (1929/1971) expanded the psychoanalytic point of view with his concept of the "social place". In Bernfeld's view, many cases of waywardness or criminality require not therapy but pedagogy; the psychological and behavioural problems seen in children and young people are the result of a "breakdown in the educational influence of their surroundings", a "lack of proper contact between the children and their surroundings" (Bernfeld, 1926, p. 277). Bernfeld also felt that problems arose from a conflict between the values and social leanings experienced in the milieu of childhood and the values and social leanings in the adult milieu. He felt that children needed to be "re-educated" to deal with these problems (Bernfeld, 1929, p. 202). This theory centres around establishing a positive social environment or milieu which influences the child's upbringing and education: children "must be brought into an environment where they find people whom they can love, treasure and admire; a community it is worth living in ... " (Bernfeld, 1926, p. 278).

Aichhorn, who developed a psychoanalytic educational program for children's residential care, was especially influential (Scheipl, 2011, p. 1343). Like Bernfeld, Aichhorn (1925) believed that residential care work was first and foremost about "re-education": to Aichhorn, the "waywardness" of youth was not a medical problem but one of upbringing (p. 14). He describes child-raising as an "art" that requires a certain level of ability (involving, e.g., impartiality, catering to individuality, understanding, and empathy [Aichhorn, 1972, pp. 97-98]), but in which the significance of psychology is often overestimated. "Residential care work is a field with many ramifications, involving not only psychological problems but also many psychiatric, sociological, politico-cultural and politico-economic problems" (Aichhorn, 1925, p. 15).

As well as rejecting the concept of pathological waywardness, Aichhorn (1925) believed that wayward youth were not "criminals" against whom society needed to be protected but "people who have been overburdened by life, whose negative attitude and hate against society was justified, and for whom a milieu thus had to be created in which they could feel at home" (p. 130). He viewed wayward youth as normal young people whose problems resulted from difficult social milieus and traumatising experiences of life.

Accordingly, re-education starts with the creation of a positive social milieu - a social environment that opens up the possibility of positive social experiences. In the institution run by Aichhorn in Hollabrunn, "every single group" was to be organised so that "merely living in the group, without any particular child-raising activities, reduces waywardness" (Aichhorn, 1972, p. 124). Aichhorn's educational program consisted in creating "experiences" for youth, arising from living with pedagogues or other people with whom they had positive emotional relationships. The context for this was a suitable social milieu. "If the pupils are to have experiences, they need to get out into life instead of being put in an institution that is out of touch with life, however pleasant it is. The less institutional the milieu is, and the closer it comes to being a free community of people with a positive attitude to life, the less alienated the dissocial individual is from real life and the more likely he is to be healed and later return to society" (Aichhorn, 1972, p. 131). 
International Journal of Child, Youth and Family Studies (2018) 9(1): 108-120

Neither Aichhorn nor Bernfeld developed an explicit theory of social pedagogy. Their ideas about child-raising are, however, based on a social pedagogical outlook that views social circumstances and the conditions of people's social environments as key causes for problems in their behaviour and development. For this reason, pedagogical work began to centre around creating an educationally productive social environment. The central significance of the social environment or milieu with regard to processes of development and education is also emphasised in other Austrian studies on youth in the 1920s and 1930s, such as those by Charlotte Bühler, Hildegard Hetzer, or Paul Lazarsfeld (Maierhofer, 1996, p. 4).

The new era of social pedagogy, signs of which can be seen in the 1920s and 1930s, did not lead to the field becoming lastingly or widely established in Austria. There were several reasons for this. First, the psychoanalytic reform movements were restricted to Vienna and met with little interest in other Austrian regions. Second, although Aichhorn set up specialist courses for his staff as early as 1921, and there were other courses for child care workers, for example, in religious institutions, no overarching, uniform vocational training method in social pedagogy was established (Scheipl \& Heimgartner, 2004, p. 129). Third, though child and youth care work initially leaned strongly towards social pedagogy, near the end of the 1920s a view based on social hygiene and medicine became increasingly established (Scheipl, 2003, p. 31). Fourth and finally, National Socialism led to the end of the psychoanalytic movement. Many of its protagonists were banned from their places of work or were forced to emigrate.

Residential care work was turned into traditional institutional education on the basis of National Socialist ideologies. It pivoted on the ideas of social and racial hygiene, which were directed not at the wellbeing of the child but at the wellbeing of the Nazi state. Classical correctional education was linked to selection strategies aimed at singling out Volksschädlinge [pests harmful to the people], Gemeinschaftsfremde [aliens to the community], and individuals described as Ballastexistenzen [dead weights] (Kreitner, 2006, pp. 98-108). In the Vienna residential care home Am Spiegelgrund this led to the killing of some 700 children in the period from 1942 to 1945 . The threat of death was deliberately used in this setting as a pedagogical means

of dealing with insubordinate behaviour (Neugebauer, 2000, p. 149). This dark chapter in the history of children's residential care in Austria only began to be acknowledged and discussed at the end of the 1970s (Scheipl, 2007, p. 148).

\section{Restoration and Establishment of Social Pedagogy}

After the Second World War there were no signs of a revival of social pedagogy. Instead, the first step taken was to restore the basic conditions needed for everyday work. One difficulty was that there was no general profile defining what made a professional social pedagogue. Until the beginning of the 1960s, social pedagogical training took place in the form of short courses and staff training, sometimes organised by individual federal states but mostly arranged by the institutions and sponsors themselves. This not only resulted in poor-quality qualifications but also made the Erzieher [child care workers], as they were now known, extremely dependent on their 
employers (Gnant, 2003, p. 464-465). The first signs of an Austria-wide professionalisation of child care workers came in 1962, with the introduction of courses at the level of the Fachschule [professional school] (Gnant, 2003, p. 463).

After the end of the Second World War, the practice of children's residential care was dominated by large, institutional homes. In the wake of the 1968 student movements, the "homes campaign" arose in Vienna, calling for opening up and decentralising the institutional homes. In 1972 the first supported group home was established in Vienna, with other group homes following in other federal states. In the 1970s this development led to the large institutions gradually being closed and the types of care available becoming more varied. Increasingly, facilities were run by private organisations (Scheipl, 2007, p. 149 et seq.). At the same time, the reform of residential care played a key role in stimulating the foundation of other kinds of social pedagogical support.

Changes in pedagogical practice led to discussions about the quality and level of training, though this did not give social pedagogy a consistent academic structure or professionalisation. From the 1980s on, existing courses for child care workers were moved to the level of higher education or colleges. In 1993 these training centres were renamed "Social Pedagogy Education Institutes" (Gnant, 2003, p. 467 et seq.). According to the Austrian School Organisation Act (SchOG), these are intended to train students for "child care work in after-school centres, residential homes, day centres and the care-related aspects of full-service community schools, as well as youth work outside schools" (SchOG quoted in Gnant, 2003, p. 462).

As well as occupational training, there were signs that social pedagogy was developing independently at Austrian universities. Social pedagogy is first mentioned explicitly as a specialist pathway as part of the degree course in educational science offered in the city of Graz from 1978 onwards. Other specialist pathways in social pedagogy were introduced in Innsbruck, Vienna, Salzburg, and Klagenfurt, though some were later dropped (Scheipl \& Heimgartner, 2004, p. 135136). The only professorships and masters courses in social pedagogy today are in Graz and Klagenfurt. Another professorship in social pedagogy was established in 2013 in Salzburg.

In other words, a firm academic basis for social pedagogy was created relatively late in Austria. So far, professionalisation has taken place at a relatively low level, with each course having a rather narrow focus. In addition, there are still regional differences and a heterogeneous landscape of social services, occupational titles, and training courses that are not subject to any overall Austrian regulations or organisation.

Alongside social pedagogy, the field of social work has also followed a separate path towards professionalisation since the start of the twentieth century, first in the form of specialist courses, then as social academies, and since 2001 in the form of courses at universities of applied science. Since the reforms of the Bologna Process and the introduction of bachelor's and master's degrees, courses in Sozialarbeit [social work] have been renamed, and are now courses in Soziale Arbeit. This relates to developments in German theory according to which the term Soziale Arbeit 
International Journal of Child, Youth and Family Studies (2018) 9(1): 108-120

stands for an overarching, integrative outlook combining social work and social pedagogy (Füssenhäuser \& Thiersch, 2011, p. 1638). So far, however, no steps have been taken in Austria towards achieving the aspiration this implies for qualifications in the field of social work and social pedagogy as a whole. Soziale Arbeit has developed from the tradition of social work, and does not so far involve many pedagogical aspects, whereas social pedagogy focuses on "pedagogical professionality" (see Sting, 2015). One consequence of this is that at some Universities of Applied Sciences, there are now not only courses in Soziale Arbeit, but also some courses in social pedagogy, which differ both from existing courses at the Social Pedagogy Education Institutes and from courses in social pedagogy that are offered in the framework of educational science at universities.

\section{Social Pedagogical Perspectives for Work with Children and Young People: Inspiration from Austrian History}

This brief outline of the historical development of social pedagogy in Austria demonstrates that though there is a vague general understanding of the subject, there is no one consistent concept for this field in Austria. It thus seems foolhardy to try to draw any general conclusions from the historical background. For this reason, in the following I would like to take some of the historical ideas behind current developments and problems in work with children and young people, and show their continued relevance.

One basic principle in Bernfeld (1926/1971, 1929/1971) and Aichhorn's (1951, 1972) social pedagogical concepts was that work with children and young people is primarily about pedagogy, not about therapy. As psychoanalysts, both were familiar with the psychological damage that can result from unfavourable circumstances in children's development. Nonetheless, they argued in favour of a less methodological approach, believing that psychological and behavioural problems are due not only to one's individual traits but also to one's relationships with one's environments and social circumstances. Accordingly, they believed that favourable developmental processes could be initiated through positive changes to the child/environment nexus. These could be achieved by creating a positive milieu or social environment that would foster the children's wellbeing.

The creation of this social environment did not focus on any particular pedagogical means or treatment. The key component was supportive, emotionally stable, social relations. In this context, Bernfeld (1926, 1929) laid the emphasis on the "solidaristic community", while Aichhorn (1951, 1972) underlined the importance of children living with people with whom they had positive emotional relationships. These ideas correspond with modern findings from both attachment theory and the theory of symbolic interactionism on the status that "significant others" can gain in processes of development.

The idea that even serious behavioural problems and psychological irregularities can be corrected by creating a social environment that encourages development and enables people to establish emotionally beneficial, supportive, social relationships implies that ultimately it is the 
International Journal of Child, Youth and Family Studies (2018) 9(1): 108-120

people involved who go through a process of change. This change thus results less from any external pedagogical effect and more from a process of Selbstbildung [self-education], which, though it can be externally precipitated, has to be initiated and achieved by the people themselves. The preeminence of self-education in processes of personal development is at the heart of thought on education in the German-speaking countries and is gaining in importance in recent research on youth welfare in Germany and Austria (see Zeller, 2012; Köngeter, Mangold, \& Strahl, 2016; Sting, 2016).

\section{Personal Development Through Changes in the Self-Environment Nexus: The Example of Chantal}

The idea that creating a suitable social environment with positive social relationships can initiate processes conducive to personal development does not suggest that treatments are ineffective or that therapy for psychological problems is unnecessary. Nonetheless, a self-initiated dynamic of change or an element of self-education also seems to be required to stimulate a lasting process of development. In this context I would like to describe one example from a current study we are carrying out at the University of Klagenfurt on educational opportunities in, and social contexts of, care leavers' educational processes, focusing on how formal educational processes are interlinked with educational careers. The example in question is a biographical interview with "Chantal". 1

At the time of the interview, Chantal was 24 years old. She lived with a flatmate in her own flat in another European country, where she worked as a deputy sous-chef in a restaurant. At the age of 13, following a suicide attempt, she spent two years in psychiatric care for children and young people, with a few brief breaks. During her time in psychiatric care, she spent her free weekends at a crisis intervention centre rather than with her family. After a failed trial run in a residential group home, at the age of 15 she entered another supported group home, where she lived until becoming independent at 18 and a half. She left mainstream schooling due to serious behavioural difficulties, and next attended a school run by the psychiatric clinic, though this also failed. Chantal associated school attendance with disinterest and rejection, which led to interruptions, non-attendance, provoking teachers, alcohol consumption during lessons, and even burning a fellow schoolgirl's hair and setting fire to a school bus. Eventually, while in the psychiatric clinic, she was given individual lessons by a teacher working for the hospital.

A serious change occurred when Chantal moved to a supported group home. Chantal initially rejected this change, but in retrospect she described it as the "best chance" of her life. There, she "started to learn how to deal with other people like normal without hitting each other or whatever and talking and kind of seeing things differently" (Chantal, lines 137-138). In order to bring her school career to a successful close, the leader of the group home worked to ensure that Chantal could complete her school education through lessons at the psychiatric clinic. Chantal felt

\footnotetext{
${ }^{1}$ The name has been anonymised. The study was carried out from April 2016 to January 2018; in this research project I worked with Maria Groinig, Wolfgang Hagleitner, and Thomas Maran.
} 
as if the carers at the group home "had her back" in a way that she stated she never experienced at home, in her family. Eventually she managed "to get through somehow and apparently everyone else thinks it's great"' (Chantal, line 284).

In the group home, Chantal evidently found a social environment that enabled her to have positive social experiences and where she experienced social esteem and recognition. To allow her to complete her school education successfully, an unconventional arrangement was established: she lived in the supported group home and was taught at the psychiatric clinic. According to Chantal, this social setting led to "something going click in my head" (Chantal, lines 362, 366367); these are the words she used to describe a self-education process through which she initiated a change in her self-environment nexus. As a result, this development was reinforced in that successfully finishing school allowed her to experience agency: she got to know more "great people", entered a supportive relationship with a partner, and received "good feedback" during the next steps in her training as a cook, which gave her confirmation that she could "do good work". She stated:

Then I thought that I really wasn't going to like knock that down by cocking things up again and that, by getting back in that rut again. So I just stuck with it and just made an effort to finish it as well as I could. (Chantal, lines 368-370)

In Chantal's case, creating a suitable social environment with positive social relationships appears to have initiated a process of self-education that was conducive to her development. She did, of course, undergo regular therapeutic treatment at the psychiatric clinic and while in the group home, and this undoubtedly contributed to the process of change, but Chantal herself did not say much about it in her biographical review. The chance to pass her school-leaving exams led to an experience of self-efficacy and agency that decisively stabilised and reinforced this positive developmental process.

Recent studies on successful care leavers have shown that a suitable social environment does not necessarily have to be provided by the youth care services: some young people find and help create social environments themselves where they can discover positive social experiences, continuity, and their own agency. Interestingly, when young people are successful at school, the school may be one such social environment. In this case, the school is not just a place to acquire skills but a place of normality and continuity that enables young people to have social recognition and positive social relationships. The study Higher Education without Family Support, which was carried out by Köngeter and colleagues (2016) at the University of Hildesheim, makes this clear. In contrast to their often chaotic experiences in their families of origin and the special world of the youth care institution, school offers young people contact with "normal" peers, socially accepted tasks and expectations, and a predictable daily structure. In this context, scholastic success can lead to the acquisition of social esteem and help them gain a better socioeconomic status than their families of origin, whose educational opportunities were often limited. At the same time it allows them to experience their own influence or agency as they learn to manage generally accepted social 
International Journal of Child, Youth and Family Studies (2018) 9(1): 108-120

expectations (Köngeter et al., 2016, pp. 113 et seq., p. 169). For one young man in our study this meant that although he had left his family at an early age and moved from one youth care placement to another several times, he completed all his upper secondary level schooling at the same school. For him, the most important condition whenever he moved to a new placement was that he could stay at his school, and the staff at the school in question supported him strongly.

Social environments other than school can also constitute a beneficial social space. In one case a young man found support in his friend's educationally inclined family; he went on holiday with them and they supported his efforts at school. In some cases, a motivating, supportive relationship with siblings creates a social environment that is conducive to education (Köngeter et al., 2016, pp. 132-133; see also Leitner, Loch, \& Sting, 2011).

\section{Conclusions}

In child and youth care, a sensitivity to the formation of social environments is necessary. These are places where positive social experiences are made possible; this in turn can spark developmentally beneficial processes of self-education. Positive personal developments do not result only from pedagogical or therapeutic work with the child; instead, they evolve out of changes in the child/environment nexus. Although the child/environment nexus can be encouraged to change by organising suitable group and living arrangements in the context of youth care, biographical studies indicate that social environments such as school, friendships, and certain elements of the context of origin (e.g., relationships with siblings or grandparents) should also be considered.

Biographies reveal a topography of heterogeneous social environments that can provide continuity, esteem, social connections, and an experience of agency, and thus trigger developmentally beneficial processes of self-education. Drawing from the concepts of milieu formation and the significance of the social environment as found in the Austrian history of social pedagogy, professionals working with children and youth need to recognise, maintain, and productively use the resources that are to be found in the biographical topographies of individuals' social environments. 
International Journal of Child, Youth and Family Studies (2018) 9(1): 108-120

\section{References}

Aichhorn, A. (1925/1951). Verwahrloste Jugend. Die Psychoanalyse in der Fürsorgeerziehung [Wayward youth. Psychoanalysis in care education]. Bern, Switzerland: Huber.

Aichhorn, A. (1972). Erziehungsberatung und Erziehungshilfe: 12 Vorträge über psychoanalytische Pädagogik. Aus dem Nachlass August Aichhorns [Educational counselling and educational support: 12 lectures about psychoanalytical pedagogy. From the inheritance of August Aichhorn]. Reinbek, Germany: Rowohlt.

Baernreither, J. M. (Ed.). (1907). Die Ursachen, Erscheinungsformen und die Ausbreitung der Verwahrlosung von Kindern und Jugendlichen in Österreich: Einzeldarstellungen aus allen Teilen Österreichs, gesammelt von dem vorbereitenden Komitee des Ersten Österreichischen Kinderschutzkongresses in Wien [Causes, manifestations and spread of waywardness among children and youth in Austria: Descriptions from all parts of Austria, collected by the preparative committee of the First Austrian Congress of Child Protection in Vienna]. Vienna, Austria: Manz.

Bernfeld, S. (1926/1971). Die psychologischen Grundlagen der Gefährdetenfürsorge [Psychological basics of care for people at risk]. In L. von Werder \& R. Wolff, (Eds.), Antiautoritäre Erziehung und Psychoanalyse [Anti-authoritarian education and psychoanalysis] (pp. 275-278). Frankfurt am Main, Germany: März.

Bernfeld, S. (1929/1971). Der soziale Ort und seine Bedeutung für Neurose, Verwahrlosung und Pädagogik [Social place and its meaning for neurosis, waywardness and education]. In L. von Werder \& R. Wolff, (Eds.), Antiautoritäre Erziehung und Psychoanalyse [Antiauthoritarian education and psychoanalysis] (pp. 198-211). Frankfurt am Main, Germany : März.

Füssenhäuser, C., \& Thiersch, H. (2011). Theorie und Theoriegeschichte Sozialer Arbeit [Theory and historical theoretical perspectives of social work]. In H.-U. Otto \& H. Thiersch (Eds.), Handbuch Soziale Arbeit [Handbook of social work] (pp. 1632-1645). Munich, Germany: Reinhardt.

Gnant, I. (2003). Die geschichtliche Entwicklung der sozialpädagogischen Berufsausbildung in Österreich [Historical development of professional training in social pedagogy in Austria]. In K. Lauermann \& G. Knapp (Eds.), Sozialpädagogik in Österreich [Social pedagogy in Austria] (pp. 460-479). Klagenfurt, Austria: Hermagoras. 
International Journal of Child, Youth and Family Studies (2018) 9(1): 108-120

Hofmann, M. (2003). Der Berufsverband Österreichischer Sozialpädagoginnen und sein Beitrag zur Professionalisierung [The Professional Association of Austrian Social Pedagogues and its contribution to professionalisation]. In K. Lauermann \& G. Knapp (Eds.), Sozialpädagogik in Österreich [Social pedagogy in Austria] (pp. 480-491). Klagenfurt, Austria: Hermagoras.

Köngeter, S., Mangold, K., \& Strahl, B. (2016). Bildung zwischen Heimerziehung und Schule [Education between residential care and school]. Weinheim, Germany: Beltz Juventa.

Kreitner, C. (2006). „Jugendfürsorge“ während des Nationalsozialismus in Kärnten (19381945) [Child and youth care during National Socialism in Carinthia (1938-1945)] (Unpublished doctoral dissertation). University of Klagenfurt, Klagenfurt, Austria. Retrieved from http://ubdocs.uni-klu.ac.at/open/hssvoll/AC05032517.pdf

Leitner, S., Loch, U., \& Sting, S. (with Schrabeck, R.). (2011). Geschwister in der Fremdunterbringung [Siblings in residential care]. Vienna, Austria: LIT.

Maierhofer, B. (1996). Ausgewählte theoretische sozialpädagogische Positionen und die Entwicklung der staatlichen Jugendfürsorge in Österreich in der Ersten Republik bzw. in der Zeit von 1928 bis 1938 [Selected theoretical positions of social pedagogy and the development of public child and youth care in Austria during the First Republic resp. the period from 1928 to 1938]. Klagenfurt, Austria: Universität Klagenfurt.

Neugebauer, W. (2000). Leben und Sterben am Spiegelgrund [Life and death at Spiegelgrund]. In J. Gross (Ed.), Spiegelgrund: Leben in NS-Erziehungsanstalten [Spiegelgrund: Life in institutional homes of the Nazis] (pp. 140-155). Vienna, Austria: Ueberreuter.

Scheipl, J. (2003). Soziale Arbeit in Österreich - ein Torso? Brüchige Entwicklungen, angedeutete Perspektiven [Social work in Austria - a body? Fracturable developments, indicated perspectives]. In K. Lauermann \& G. Knapp (Eds.), Sozialpädagogik in Österreich [Social pedagogy in Austria] (pp. 10-42). Klagenfurt, Austria: Hermagoras.

Scheipl, J. (2007). Geschichte der Sozialpädagogik in Österreich - unter besonderer Berücksichtigung der Jugendwohlfahrt [The history of social pedagogy in Austria considering particularly child and youth care]. In G. Knapp \& S. Sting (Eds.), Soziale Arbeit und Professionalität im Alpen-Adria-Raum [Social work and professionalism in the AlpsAdriatic region] (pp. 134-157). Klagenfurt, Austria: Hermagoras.

Scheipl, J. (2011). Soziale Arbeit in Österreich [Social work in Austria). In H.-U. Otto \& H. Thiersch (Eds.), Handbuch Soziale Arbeit [Handbook of Social Work] (pp. 1342-1348). Munich, Germany: Reinhardt. 
International Journal of Child, Youth and Family Studies (2018) 9(1): 108-120

Scheipl, J., \& Heimgartner, A. (2004). Ausbildung für Soziale Berufe in Österreich [Training for social professions in Austria]. In F. Hamburger, S. Hirschler, G. Sander, \& M. Wöbcke (Eds.), Ausbildung für soziale Berufe in Europa [Training for social professions in Europe] (pp. 114-139). Frankfurt am Main, Germany: Pontifex.

Sting, S. (2015). Disziplin und Differenz [Discipline and difference]. Soziales Kapital, 14, 194202. Retrieved from http://sozialeskapital.at/index.php/sozialeskapital/article/viewFile/394/678.pdf

Sting, S. (2016). Bildung im sozialen Raum. Überlegungen zu einer sozialpädagogischen Konzeption von Bildung [Education in social space. Considerations about a social pedagogical conception of education]. Zeitschrift für Sozialpädagogik, 14, 118-139.

Winkler, M. (2010). Professionalisierung der Sozialpädagogik? [Professionalisation in social pedagogy?] Sozialpädagogische Impulse, 3, 44-46.

Zeller, M. (2012). Bildungsprozesse von Mädchen in den Erziehungshilfen [Educational processes among girls in child and youth care]. Weinheim, Germany: Beltz Juventa. 